\title{
Contributions of androgen and estrogen to fetal programming of ovarian dysfunction
} David H Abbott*1, Vasantha Padmanabhan ${ }^{2}$ and Daniel A Dumesic ${ }^{1,3}$

\author{
Address: ${ }^{1}$ National Primate Research Center, Department of Ob/Gyn, and Endocrinology-Reproductive Physiology Training Program, University \\ of Wisconsin, Madison, WI 53715, USA, 2Departments of Pediatrics, Ob/Gyn, Cellular and Integrative Physiology, and Reproductive Sciences \\ Program, University of Michigan, Ann Arbor, MI 48109, USA and ${ }^{3}$ Reproductive Medicine \& Infertility Associates, Woodbury, MN 55125, USA \\ Email: David H Abbott* - abbott@primate.wisc.edu; Vasantha Padmanabhan - vasantha@umich.edu; \\ Daniel A Dumesic - drdumesic@rmia.com \\ * Corresponding author \\ Published: 10 April 2006 \\ Reproductive Biology and Endocrinology2006, 4:17 doi:10.1 186/1477-7827-4-17 \\ This article is available from: http://www.rbej.com/content/4/I/I7 \\ (C) 2006Abbott et al; licensee BioMed Central Ltd. \\ This is an Open Access article distributed under the terms of the Creative Commons Attribution License (http://creativecommons.org/licenses/by/2.0), \\ which permits unrestricted use, distribution, and reproduction in any medium, provided the original work is properly cited.
}

\begin{abstract}
In female mammals, including humans, deviations from normal androgenic or estrogenic exposure during fetal development are detrimental to subsequent adult ovarian function. Androgen deficiency, without accompanying estrogen deficit, has little apparent impact on ovarian development. Fetal estrogen deficiency, on the other hand, results in impaired oocyte and follicle development, immature and abnormal adult ovaries, and excessive ovarian stimulation from endogenous gonadotropins ultimately generating hemorrhagic follicles. Complete estrogen deficiency lasting into adulthood results in partial ovarian masculinization. Fetal androgen excess, on the other hand, mediated either by direct androgen action or following androgen aromatization to estrogen, reprograms ovarian development and reproductive neuroendocrinology to mimic that found in women with polycystic ovary syndrome: enlarged, polyfollicular, hyperandrogenic, anovulatory ovaries with accompanying LH hypersecretion. Oocyte developmental competence is also compromised. Insulin is implicated in the mechanism of both anovulation and deficient oocyte development. Fetal estrogen excess induces somewhat similar disruption of adult ovarian function to fetal androgen excess. Understanding the quality of the fetal female sex steroid hormone environment is thus becoming increasingly important in improving our knowledge of mechanisms underlying a variety of female reproductive pathologies.
\end{abstract}

\section{Introduction}

Impaired fetal growth and subsequent adult cardiovascular disease [1] provide the best known example of fetal programming of adult pathology. Fetal programming is triggered when a stimulus or insult occurs at a gestational age critical for target organ differentiation, growth or development and induces permanent changes in organ size, structure or function. Developmental insults to the fetus, such as low calorie or low protein maternal diets, program for hypertension, insulin resistance, type 2 dia- betes and obesity in adulthood [2]. Fetal glucocorticoid excess also programs many of the same adult traits induced by low calorie and low protein maternal diets, and has been proposed as the common physiological mechanism translating maternal environmental factors into impaired fetal growth and fetal programming of organ function [3].

Steroid hormone excess, including glucocorticoid and sex hormone excess during fetal life, is well known to induce 
Table I: Summary of major reproductive dysfunction or anomalies associated with fetal deficiency or excess of androgen or estrogen

\begin{tabular}{|c|c|c|c|c|}
\hline \multirow[t]{2}{*}{ Major reproductive dysfunction/anomaly } & \multicolumn{2}{|c|}{ Fetal deficiency of: } & \multicolumn{2}{|c|}{ Fetal excess of: } \\
\hline & Androgen ${ }^{b}$ & Estrogen ${ }^{a}$ & Androgen & Estrogen \\
\hline \multicolumn{5}{|l|}{ Ovarian } \\
\hline Reduced ovulatory frequency & $+[29]$ & $+[45]$ & $+[12,50-56]$ & $+[15,76,80,81]$ \\
\hline Reduced follicle number & ? & $+[33,44]$ & $+[69]$ & $+[14,77]$ \\
\hline Reduced ovarian response to FSH & $+[29]$ & $+[42,43]$ & $+[69]$ & ? \\
\hline $\begin{array}{l}\text { Excessive, endogeneous hypergonadotropic- } \\
\text { inducing hemorrhagic follicles }\end{array}$ & - & $+[38,45]$ & - & - \\
\hline Ovarian hyperandrogenism & - & $+[38]$ & $+[49,53]$ & $+[77,79]$ \\
\hline Polycystic ovaries & ? & - & $+[13,52,57]$ & $?$ \\
\hline Impaired oocyte developmental competence & $?$ & ? & $+[28,69,70]$ & $?$ \\
\hline Partial masculinization of the ovary & - & $+[47,48]$ & - & - \\
\hline Premature ovarian senescence & ? & ? & $+[50-52]$ & $?$ \\
\hline \multicolumn{5}{|l|}{ Neuroendocrine } \\
\hline Increased LH levels & $?$ & $+[24,38,45]$ & $+[12,53,56,60]$ & ? \\
\hline Increased FSH levels & ? & $+[24,45]$ & - & ? \\
\hline $\begin{array}{l}\text { De-sensitized estradiol/progesterone negative } \\
\text { feedback on LH }\end{array}$ & ? & $?$ & $+[49,53-56,58-60]$ & ? \\
\hline Increased gonadotrope LH sensitivity to $\mathrm{GnRH}$ & ? & ? & $+[49]$ & ? \\
\hline
\end{tabular}

a : as discussed in the text, many instances of fetal androgen and estrogen deficiencies persist into adult life and partially confound assessments of the precise causes of the reproductive abnormalities found.

$b$ : abnormalities summarized in this table reflect studies in which there were no concomitant deficiencies in estrogen

permanent alterations in adult female phenotype. For example, fetal androgen excess induces female uro-genital virilization along with masculinized behavior, and neural anatomy and function [4], while fetal estrogen excess results in female reproductive tract abnormalities, including clear cell adenocarcinoma of the vagina and cervix, as well as increased risk of breast cancer [5]. Less is known, however, about fetal progestin excess which can mimic androgen excess in its fetal programming outcomes $[6,7]$. Steroid hormones mediate their classical or genomic actions by binding to nuclear receptors and engaging a variety of molecular chaperones permitting ultimate binding of the entire complex to steroid response elements on promoters of target genes [8]. Nonclassical or nongenomic actions of steroids, including rapid changes in cytoplasmic protein function without steroid-receptor complex binding to DNA, are mediated by cell membrane receptors such as GPR30, a G-protein coupled protein mediating rapid estrogen action (estrogen membrane receptor: [9]; androgen membrane receptor: [10]; progesterone membrane receptor: [11]). Whether prenatal steroid hormone programming of postnatal ovarian function involves either or both classical and non-classical action is not known. Studies to date have assumed a classical or genomic action.

It is certainly becoming clear that exposing female fetuses to androgen excess results in enlarged adult ovaries that are polyfollicular, anovulatory and hyperandrogenic, and resemble those found in women with polycystic ovary syndrome (PCOS: monkeys: [12]; sheep: [13]). Fetal estrogen excess, on the other hand, diminishes ovarian size and function while increasing anovulation in adulthood [14-16]. This mini-review will focus on the role of fetal androgens and estrogens in determining postnatal ovarian phenotype (summarized in Table 1), and the relevance of such fetal programming to reproductive health in women.

\section{Fetal androgen deficiency}

Within the ovary, androgens are synthesized mainly within theca cells and the ovarian stroma, while mural granulosa cells convert theca-cell derived androstenedione into testosterone and dihydrotestosterone (DHT). Since androgen receptors are expressed in the fetal ovary [17] and in oocytes, granulosa and theca cells, and ovarian stroma in the mature, adult ovary [18-20], androgen action can effect many components of ovarian development and cyclical function [21].

Discrete experimental induction of fetal androgen deficiency induced by the administration of flutamide to pregnant rhesus monkeys during either early or late gestation fails to alter age at menarche and at first ovulation in exposed female fetuses [22]. Fetal deficiencies in female androgen biosynthesis induced by congenital defect or experimentally induced knockout of mitochondrial steroidogenic acute regulatory protein (StAR; [23]), and steroid biosynthetic enzyme, P450c17 [24,25], however, produce obvious defects in ovarian function, but androgen deficiencies also persist into postnatal life. Androgen deficiencies in adult female StAR knockout mice result in 
undectectable circulating levels of testosterone, extremely low levels of progesterone and corticosterone, and a poorly developed reproductive tract, indicative of hypoestrogenism [23]. Not surprisingly, the ovaries fail to show major follicle development or the presence of corpora lutea, but they do become enlarged due to hypertrophy of the stroma under endogenous hypergonadotropic overstimulation. Similar to the androgen deficiency produced by defective or absent StAR, women deficient in the biosynthetic enzyme, P450c17, show marked impairment in androgenic, estrogenic and glucocorticoid biosynthesis [26], as well as anovulatory, hypergonadotropic hypogonadism. The ovaries are devoid of major follicle development, but experimentally-induced gonadotropic ovarian hyperstimulation for in vitro fertilization (IVF) induces the growth of dominant follicles that yield fertilizable oocytes at retrieval. None of the fertilized oocytes, however, progress beyond the 7-cell embryonic stage [24], and fail to reach developmental stages when they are completely dependent on the embryonic genome [27]. Such impaired embryonic developmental competence probably reflects a sub-optimal intra-follicular estrogenic environment due to deficient production of androgen precursors for estrogen biosynthesis by mural granulosa cells [28].

When life-long androgen deficiencies do not concomitantly result in fetal estrogen deficiencies, such as in androgen receptor knockout (ARKO) female mice, there are only subtle impairments in adult ovarian function (Table 1). While ovarian follicle counts are similar to those in wild type mice, ARKO mice have fewer estrus cycles, smaller litter sizes, yield fewer oocytes upon gonadotropic hyperstimulation, and exhibit a diminished granulosa cell layer within follicles and smaller-sized corpora lutea [29]. Androgens may thus play important roles in the adult ovary supporting ovarian follicle and oocyte maturation, as found by Bondy and colleagues [30-32] when they treated adult female rhesus monkeys with testosterone. Unlike estrogens, however, androgens are not apparently required during fetal life for normal ovarian development.

\section{Fetal estrogen deficiency}

Studies repeatedly implicate a key role for fetal estrogen in the normal development of ovarian morphology and function (Table 1). Exposure of fetal female baboons to a hypoestrogenic environment, by treating their pregnant mothers with an aromatase inhibitor during mid- to late gestation, halves the numbers of primordial follicles found in fetal ovaries at late gestation [33], and drastically reduces the numbers of oocyte-granulosa cell microvilli [34] that are essential for oocyte nutrition and oocytegranulosa cell intra-follicular communication [35]. Concomitant treatment of pregnant mothers with aromatase inhibitor and estradiol prevents the late gestation ovarian consequences induced by inhibitor treatment, alone, and specifically implicates estradiol in the normal development of ovarian follicles [33,34]. Whether these fetal ovarian deficiencies translate into abnormal adult ovarian function is not yet known.

Estrogen deficiencies that are manifest beyond fetal life, as found in estrogen receptor or aromatase knockout female mice, while confounded in terms of manifesting specific fetal programming effects, provide additional insight into discrete components of estrogen action involved in ovarian development and function. ER $\alpha$ receptor expression is found in theca cells and ovarian stroma, while ER $\beta$ receptor is located in granulosa cells of growing follicles $[36,37]$. Given their differing ovarian locations, it is not surprising that the inability of estrogen to bind to the ER $\alpha$ receptor (ERKO) produces different abnormalities than those found in ER $\beta$ receptor knockout (BERKO) mice. ERKO female mice exhibit an ovarian phenotype of chronic anovulation, cystic and hemorrhagic follicles, absent corpora lutea, interstitial/stromal hyperplasia, and elevated plasma estradiol and testosterone levels in the presence of luteinizing hormone (LH) excess [38]. Since gonadotropin-releasing hormone $(\mathrm{GnRH})$ analogue treatment normalizes LH levels and ovarian morphology in ERKO mice, and gonadotropin ovarian hyperstimulation results in ovulation, many of the ovarian abnormalities appear secondary to the loss of ER $\alpha$-mediated negative feedback regulation of LH at the hypothalamus-pituitary level $[39,40]$. In contrast to ERKO mice, BERKO animals are ovulatory, circulating LH levels are normal, and females give birth to live young, albeit with reduced numbers of corpora lutea and smaller litter sizes [41]. The ovarian phenotype in BERKO mice thus reflects impairments in estrogen action within the ovary related to follicle maturation and differentiation $[42,43]$. In aromatase knockout (ArKO) mice, devoid of estrogen synthesis rather than estrogen action, the numbers of primordial follicles are reduced apparently due to their lack of formation from fetal germ cell nests and to precocious activation of follicle growth from the primordial pool [44]. In the complete absence of estrogen, ArKO females are anovulatory, folliculogenesis is arrested at the antral stage, and the ovaries manifest hemorrhagic cysts due to endogenous hypergonadotropism [45].

Unexpectedly, the adult ovarian phenotype of double estrogen receptor knockout mice $(\alpha \beta E R K O)$ is masculinized, with a concomitant reduction in oocyte number. An absence of estrogen action was previously considered relatively unimportant in female mammalian differentiation [4], except for differentiation of the brain [46]. Structures resembling testicular seminferous tubules, however, are present in the ovaries of $\alpha \beta E R K O$ mice, the ovaries express two genes involved in Sertoli cell differentiation, 


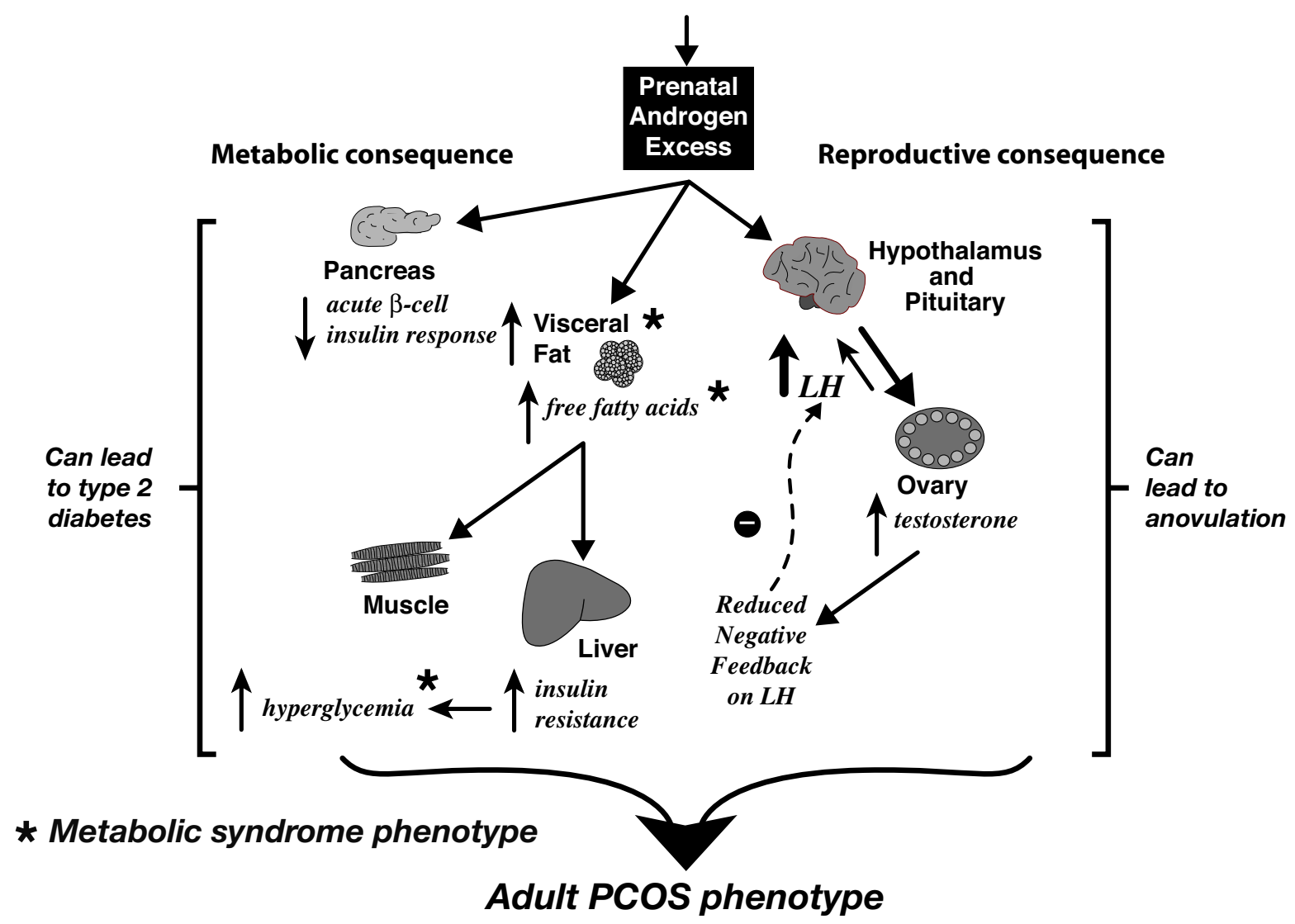

Figure I

Summary of the fetal origins hypothesis for androgen excess programming of polycystic ovary syndrome (PCOS) in the prenatally androgenized female rhesus monkey, a nonhuman primate model for PCOS in women.

sulfated glycoprotein-2 and Sox9, and an additional gene involved in androgen biosynthesis, $17 \beta-H s d-3$, that is normally expressed only in Leydig cells $[39,47]$. There is even more dramatic masculinization of the ovaries of ArKO mice. Postpubertally, ArKO ovaries possess Sertoli and Leydig cells, express Sox9, and over-express genes coding for androgen biosynthesis [48]. Since both $\alpha \beta E R K O$ and ArKO mice possess female and not male reproductive tracts, and follicles contain oocytes and not male-like germ cells, estrogen appears to play a key role in maintaining adult ovarian somatic cell phenotype [48] rather than in differentiating a fetal ovary. In humans, in comparison, while congenital aromatase deficiency leads to hyperandrogenic, multicystic ovarian phenotypes, and elevated LH and FSH levels are normalized by exogenous estrogen treatment [24], the ovaries of such women have yet to be examined for the presence of testicular structures and gene expression.

\section{Fetal androgen excess}

In contrast to fetal androgen deficiency, fetal androgen excess has striking consequences for adult ovarian function (Table 1, [49]). Female rhesus monkeys [12], sheep [50-52], mice [53] and rats [54-56] exposed, in utero, to excessive levels of either testosterone or its non-aromatizable metabolite, dihydrotestosterone, exhibit intermittent or absent ovulatory cycles in adulthood. The ovaries are also enlarged and polyfollicular in prenatally androgenized monkeys and sheep [57,13], and such females have been shown to be hyperandrogenic in prenatally androgenized monkeys and mice [49,53,57]. Hypothalamicpituitary regulation of $\mathrm{LH}$ release is deranged in prenatally 
androgen-treated females from all four species resulting in LH hypersecretion, probably driven by enhanced frequency or amplitude of hypothalamic GnRH release that, in turn, may be due to desensitization of the hypothalamus to negative feedback of estradiol and progesterone $[49,53,56,58-60]$ and/or increased pituitary sensitivity to GnRH [49]. These androgen excess phenotypes are remarkably similar to those of women with polycystic ovary syndrome (PCOS), suggesting a fetal origin for this highly prevalent women's health disorder [61].

Administration of flutamide, an antagonist of the classical androgen receptor, to adult prenatally androgenized female mice, normalizes both hypothalamic function and cyclicity, suggestive of a role for adult hyperandrogenism in these disruptions [53]. In addition to altered androgen action, impaired insulin action may also contribute to fetal androgen excess programming of anovulation since treatment of adult, prenatally androgenized female monkeys with pioglitazone, a PPARgamma receptor ligand and insulin sensitizer, normalizes menstrual cycles [62]. In this regard, it is interesting to note that fetal androgen excess programs for metabolic dysfunction, including insulin resistance (monkeys: [49,63]; sheep: [64]) and abdominal obesity (monkeys: [65]), additional symptoms commonly found in women with PCOS, as illustrated in the fetal origins of PCOS hypothesis outlined in Figure 1. Altered glucose homeostasis and excessive insulin stimulation of ovarian follicles and oocytes may thus provide further disruption of adult ovarian function and oocyte development (see below).

In prenatally androgenized ewes, fetal testosterone excess not only leads to polycystic ovarian morphology [13], but also diminishes overall ovarian reserve and increases follicular recruitment by accelerating follicle development to primary through antral stages, thus depleting the proportion of follicles remaining in the primordial pool [66]. If such accelerated follicle recruitment continues into adult life, without compensatory reduction in follicle atresia [67] or an increase in postnatal follicle recruitment [68], premature reproductive senescence will occur, as found in three separate studies of prenatally androgenized animals [50-52]. Recent studies have found follicular persistence contributes toward the multifollicular morphology in prenatal testosterone-treated sheep [52]. Whether such ovarian abnormalities are dependent on ovarian overstimulation by LH hypersecretion remains to be determined.

In prenatally androgenized female rhesus monkeys, controlled ovarian hyperstimulation for IVF yields oocytes deficient in developmental competence $[28,69,70]$. While re-initiation of meiosis, maturation and fertilization appear normal, oocytes from prenatally androgenized females progress sub-normally during the early embryonic stages. Females monkeys exposed to androgen excess during early gestation are particularly deficient and fertilized oocytes progress to blastocyst at only $13 \%$ of the numbers found in normal monkeys [28]. Intrafollicular steroidogenic responses to gonadotropic stimulation are also abnormal. Follicular fluid concentrations of androstenedione and estradiol following recombinant human (rh)FSH stimulation, alone, are diminished [69], while intrafollicular progestogenic responses to combined rhFSH stimulation followed by rhCG administration are exaggerated [28]. Since androgens [21,30,71], estrogens $[72,73]$ and an appropriate progesterone to estradiol ratio $[74,75]$ all enhance oocyte development in primates, the abnormal intrafollicular environment of prenatally androgenized female monkeys may contribute to their inferior oocyte quality. Dysregulation of LH and insulin secretion in prenatally androgenized females may additionally contribute to oocyte impairments $[28,70]$.

\section{Fetal estrogen excess}

The ovarian consequences of fetal estrogen excess are surprisingly similar to those for fetal androgen excess [76], suggesting that some components of androgen programming may be mediated by conversion of testosterone to estradiol. Since fetal female exposure to the non-aromatizable androgen, DHT, however, induces anovulation and LH hypersecretion in a similar manner to fetal testosterone excess $[53,56]$, direct androgen action in the female fetus also re-programs adult reproductive function.

Exposure of non-primate female fetuses to diethylstilbestrol (DES), a potent estrogen, results in anovulation in adulthood [76], mainly through dysfunctional neuorendocrine regulation of hypothalamic $\mathrm{GnRH}$ release. There also appear to be direct effects on the ovary. In female mice exposed to DES during fetal life, adult ovarian size is diminished, follicle numbers are reduced, there is relative hyperplasia of ovarian stroma, and cultured ovarian tissue is hyperandrogenic $[14,77]$. Transplantation of DES-exposed fetal ovaries under the kidney capsule of ovariectomized, normal adult females fails to normalize ovarian morphology, implicating a direct ovarian effect of fetal estrogen excess programming [78]. Such fetal estrogen excess in women induces moderate hyperandrogenism [79], intermittent or absent menstrual cycles and reduced fertility $[15,80,81]$. Not all studies, however, find fetal DES-programmed ovarian abnormalities [82], possibly due to reduced duration of fetal DES exposure. Many of the estrogen-programmed ovarian abnormalities appear to be mediated through DES binding to ER $\alpha$ [83]. Such ovarian impact of in utero estrogen excess suggests that fetal exposure to environmental or dietary chemicals that bind to estrogen receptors may result in similar reprogramming of ovarian function in adulthood [84,85]. 
In this latter regard, there is a potential fetal programming link between in utero estrogen and androgen excess: exposure of fetal rats to DES or to environmental toxicants with estrogenic activity, such as bisphenol A, increases binding activity at the androgen receptor [86]. Additionally, aromatization of androgen to estrogen may provide a crucial step in direct fetal programming of ovarian function, since fetal exposure to non-aromatizable DHT fails to induce abnormal ovarian morphology in prenatally androgenized ewe lambs [13].

\section{Conclusion}

Sufficient fetal estrogen, but not androgen, is crucial for the normal development of oocytes and ovarian follicles. Estrogen deficiencies lead to a reduced compliment of oocytes and follicles, and abnormal ovarian function in adulthood. When estrogen deficiency is complete, such as in ArKO mice, partially masculinized ovaries develop providing a relatively new understanding of the role of estrogen in maintaining ovarian somatic cell phenotype. When estrogen deficiencies are confined to fetal life, however, it is not yet clear whether abnormalities manifest in adulthood. In contrast, discrete in utero excess of estrogen or androgen results in abnormal programming of ovarian function that includes anovulation and hyperandrogenism. Such reproductive abnormalities appear to involve both estrogenic and androgenic actions, since not all can be explained in terms of aromatization of androgen to estrogen. Fetal androgen excess, nevertheless, is the most clinically relevant since it closely mimics the phenotype of women with PCOS and implicates similar fetal perturbations in the developmental origin of this common human endocrine pathology.

\section{Acknowledgements}

We thank the many staff members of our respective laboratories and institutions for their multiple contributions to the work reported here. This work was supported by NIH grants P50 HD044405, UOI HD044650, ROI RRO I3635, R2I RROI4093, T32 AG000268, P5I RR000 I67, ROI

HD04I098 and POI HD044232, and was partly conducted at a facility constructed with support from Research Facilities Improvement Program grant numbers RRI5459-0I and RR020I4I-0I.

\section{References}

I. Barker DJP: Mothers, babies and health in later life Churchill Livingstone, Edinburgh; 1994.

2. Ozanne SE: Metabolic programming in animals. Br Med Bull 200I, 60:143-I52.

3. Seckl JR: Physiologic programming of the fetus. Clin Perinatol 1998, 25:939-962. vii

4. Goy RW, McEwen BS: Sexual Differentiation Of The Brain Cambridge, Massachusetts, MIT Press; 1980.

5. Veurink M, Koster M, Berg LT: The History of DES, Lessons to be Learned. Pharm World Sci 2005, 27: I39- 143.

6. Saunders FJ: Effects of sex steroids and related compounds on pregnancy and on development of the young. Physiol Rev 1968, 48:60I-643.

7. Shirkey HC: Human experiences related to adverse drug reactions to the fetus or neonate from some maternally administered drugs. Adv Exp Med Biol 1972, 27:17-30.
8. Ratajczak T, Ward BK, Minchin RF: Immunophilin chaperones in steroid receptor signalling. Curr Top Med Chem 2003, 3:1348-1357.

9. Filardo EJ, Thomas P: GPR30: a seven-transmembrane-spanning estrogen receptor that triggers EGF release. Trends Endocrinol Metab 2005, 16:362-367.

10. Thomas P, Dressing G, Pang Y, Berg H, Tubbs C, Benninghoff A, Doughty K: Progestin, estrogen and androgen G-protein coupled receptors in fish gonads. Steroids in press. 2005, Nov II

II. Schwarzenbach H, Manna PR, Stocco DM, Chakrabarti G, Mukhopadhyay AK: Stimulatory effect of progesterone on the expression of steroidogenic acute regulatory protein in MA-10 Leydig cells. Biol Reprod 2003, 68:1054-1063.

12. Abbott DH, Dumesic DA, Eisner JR, Colman RJ, Kemnitz JW: Insights into the development of polycystic ovary syndrome (PCOS) from studies of prenatally androgenized female rhesus monkeys. Trends in Endocrinology and Metabolism 1998, 9:62-67.

13. West C, Foster DL, Evans NP, Robinson J, Padmanabhan V: Intra-follicular activin availability is altered in prenatally-androgenized lambs. Mol Cell Endocrinol 200I, I 85:5I-59.

14. Newbold RR, Bullock BC, Mc Lachlan JA: Exposure to diethylstilbestrol during pregnancy permanently alters the ovary and oviduct. Biol Reprod 1983, 28:735-744.

15. Haney AF, Hammond CB, Soules MR, Creasman WT: Diethylstilbestrol-induced upper genital tract abnormalities. Fertil Steril I979, 3 I: 142.

16. Herbst AL, Hubby MM, Azizi F, Makii MM: Reproductive and gynecologic surgical experience in diethylstilbestrol-exposed daughters. Am J Obstet Gynecol 198I, I 4I:I019-1028.

17. Wilson CM, McPhaul MJ: $A$ and $B$ forms of the androgen receptor are expressed in a variety of human tissues. Mol Cell Endocrinol 1996, I 20:5I-57.

18. Horie K, Takakura K, Imai K, Liao S, Mori T: Immunohistochemical localization of androgen receptor in the human endometrium, decidua, placenta and pathological conditions of the endometrium. Hum Reprod 1992, 7:146|- 466.

19. Hillier SG, Tetsuka M, Fraser HM: Location and developmental regulation of androgen receptor in primate ovary. Hum Reprod 1997, I 2:107-III.

20. Weil SJ, Vendola K, Zhou J, Adesanya OO, Wang J, Okafor J, Bondy $\mathrm{CA}$ : Androgen receptor gene expression in the primate ovary: cellular localization, regulation, and functional correlations. J Clin Endocrinol Metab 1998, 83:2479-2485.

21. Hickey TE, Marrocco DL, Gilchrist RB, Norman RJ, Armstrong DT: Interactions between androgen and growth factors in granulosa cell subtypes of porcine antral follicles. Biol Reprod 2004, 71:45-52.

22. Zehr JL, Van Meter PE, Wallen K: Factors regulating the timing of puberty onset in female rhesus monkeys (Macaca mulatta): role of prenatal androgens, social rank, and adolescent body weight. Biol Reprod 2005, 72: 1087-1094.

23. Hasegawa T, Zhao L, Caron KM, Majdic G, Suzuki T, Shizawa S, Sasano $H$, Parker KL: Developmental roles of the steroidogenic acute regulatory protein (StAR) as revealed by StAR knockout mice. Mol Endocrinol 2000, I4: I 462-147I.

24. Palter SF, Tavares AB, Hourvitz A, Veldhuis JD, Adashi EY: Are estrogens of import to primate/human ovarian folliculogenesis? Endocr Rev 2001, 22:389-424.

25. Miller WL: Disorders of androgen synthesis - from cholesterol to dehydroepiandrosterone. Med Princ Pract 2005, I4(Suppl I):58-68.

26. Yanase T, Simpson ER, Waterman MR: 17 alpha-hydroxylase/ 17,20-lyase deficiency: from clinical investigation to molecular definition. Endocr Rev 1991, 12:91-108.

27. Edwards RG: The preimplantation and implanting human embryo. In Embryonic medicine and therapy Edited by: Jauniaux $\mathrm{E}$, Barnea E, Edwards RG. Oxford, Oxford University Press; 1997:3-31.

28. Dumesic DA, Schramm RD, Peterson E, Paprocki AM, Zhou R, Abbott DH: Impaired developmental competence of oocytes in adult prenatally androgenized female rhesus monkeys undergoing gonadotropin stimulation for in vitro fertilization. J Clin Endocrinol Metab 2002, 87: I III-IIII9.

29. Hu YC, Wang PH, Yeh S, Wang RS, Xie C, Xu Q, Zhou X, Chao HT, Tsai MY, Chang C: Subfertility and defective folliculogenesis in female mice lacking androgen receptor. Proc Natl Acad Sci USA 2004, I0I:I|209-II2I4. 
30. Vendola KA, Zhou J, Adesanya OO, Weil SJ, Bondy CA: Androgens stimulate early stages of follicular growth in the primate ovary. J Clin Invest 1998, I 0 I:2622-2629.

31. Vendola K, Zhou J, Wang J, Famuyiwa OA, Bievre M, Bondy CA: Androgens promote oocyte insulin-like growth factor I expression and initiation of follicle development in the primate ovary. Biol Reprod 1999, 6 I:353-357.

32. Weil S, Vendola K, Zhou J, Bondy CA: Androgen and follicle-stimulating hormone interactions in primate ovarian follicle development. / Clin Endocrinol Metab 1999, 84:295 I-2956.

33. Zachos NC, Billiar RB, Albrecht ED, Pepe GJ: Developmental regulation of baboon fetal ovarian maturation by estrogen. Biol Reprod 2002, 67: I I48-I I56.

34. Zachos NC, Billiar RB, Albrecht ED, Pepe GJ: Regulation of oocyte microvilli development in the baboon fetal ovary by estrogen. Endocrinology 2004, I 45:959-966.

35. Cecconi S, Ciccarelli C, Barberi M, Macchiarelli G, Canipari R: Granulosa cell-oocyte interactions. Eur J Obstet Gynecol Reprod Biol 2004, I I 5(SuppI I):SI9-22.

36. Sar M, Welsch F: Differential expression of estrogen receptorbeta and estrogen receptor-alpha in the rat ovary. Endocrinology 1999, I40:963-97I.

37. Sharma SC, Clemens JW, Pisarska MD, Richards JS: Expression and function of estrogen receptor subtypes in granulosa cells: regulation by estradiol and forskolin. Endocrinology 1999, 1 40:4320-4334.

38. Couse JF, Yates MM, Sanford R, Nyska A, Nilson JH, Korach KS: Formation of cystic ovarian follicles associated with elevated luteinizing hormone requires estrogen receptor-beta. Endocrinology 2004, I 45:4693-4702.

39. Couse JF, Korach KS: Contrasting phenotypes in reproductive tissues of female estrogen receptor null mice. Ann N Y Acad Sci 200I, 948: I-8.

40. Couse JF, Bunch DO, Lindzey J, Schomberg DW, Korach KS: Prevention of the polycystic ovarian phenotype and characterization of ovulatory capacity in the estrogen receptor-alpha knockout mouse. Endocrinology 1999, I40:5855-5865.

4I. Krege JH, Hodgin JB, Couse JF, Enmark E, Warner M, Mahler JF, Sar $M$, Korach KS, Gustafsson JA, Smithies O: Generation and reproductive phenotypes of mice lacking estrogen receptor beta. Proc Natl Acad Sci USA 1998, 95: I5677-I5682.

42. Couse JF, Yates MM, Deroo BJ, Korach KS: Estrogen receptorbeta is critical to granulosa cell differentiation and the ovulatory response to gonadotropins. Endocrinology 2005 146:3247-3262.

43. Emmen JM, Couse JF, Elmore SA, Yates MM, Kissling GE, Korach KS: In vitro growth and ovulation of follicles from ovaries of estrogen receptor (ER)\{alpha\} and $E R\{$ beta\} null mice indicate a role for $E R\{b e t a\}$ in follicular maturation. Endocrinology 2005, I 46:2817-2826.

44. Britt KL, Saunders PK, McPherson SJ, Misso ML, Simpson ER, Findlay JK: Estrogen actions on follicle formation and early follicle development. Biol Reprod 2004, 71:1712-1723.

45. Britt KL, Findlay JK: Estrogen actions in the ovary revisited. J Endocrinol 2002, I 75:269-276.

46. Dohler KD, Hancke JL, Srivastava SS, Hofmann C, Shryne JE, Gorski RA: Participation of estrogens in female sexual differentiation of the brain; neuroanatomical, neuroendocrine and behavioral evidence. Prog Brain Res 1984, 6 I:99-II7.

47. Couse JF, Yates MM, Walker VR, Korach KS: Characterization of the hypothalamic-pituitary-gonadal axis in estrogen receptor (ER) Null mice reveals hypergonadism and endocrine sex reversal in females lacking ERalpha but not ERbeta. Mol Endocrinol 2003, I 7:1039-1053.

48. Britt KL, Stanton PG, Misso M, Simpson ER, Findlay JK: The effects of estrogen on the expression of genes underlying the differentiation of somatic cells in the murine gonad. Endocrinology 2004, I 45:3950-3960.

49. Abbott DH, Barnett DK, Bruns CM, Dumesic DA: Androgen excess fetal programming of female reproduction: a developmental aetiology for polycystic ovary syndrome? Hum Reprod Update 2005, I I:357-374.

50. Clarke IJ, Scaramuzzi RJ, Short RV: Ovulation in prenatally androgenized ewes. J Endocrinol 1977, 73:385-389.

51. Birch RA, Padmanabhan V, Foster DL, Unsworth WP, Robinson JE: Prenatal programming of reproductive neuroendocrine function: fetal androgen exposure produces progressive disruption of reproductive cycles in sheep. Endocrinology 2003, | 44: |426-|434.

52. Manikkam M, Steckler TS, Welch KB, Inskeep EK, Padmanabhan V: Fetal Programming: Prenatal Testosterone Treatment Leads to Follicular Persistence/Luteal Defects. Partial Restoration of Ovarian Function by Cyclic Progesterone Treatment. Endocrinology in press. 2005, Dec 22

53. Sullivan SD, Moenter SM: Prenatal androgens alter GABAergic drive to gonadotropin-releasing hormone neurons: implications for a common fertility disorder. Proc Natl Acad Sci USA 2004, 101:7129-7I34.

54. Swanson HE, Werff ten Bosch JJ: The "early-androgen" syndrome; effects of pre-natal testosterone propionate. Acta Endocrinol (Copenh) 1965, 50:379-390.

55. Fels E, Bosch LR: Effect of prenatal administration of testosterone on ovarian function in rats. Am J Obstet Gynecol 1971, I I I:964-969.

56. Foecking EM, Szabo M, Schwartz NB, Levine JE: Neuroendocrine consequences of prenatal androgen exposure in the female rat: absence of luteinizing hormone surges, suppression of progesterone receptor gene expression, and acceleration of the gonadotropin-releasing hormone pulse generator. Biol Reprod 2005, 72:|475-1483.

57. Abbott DH, Dumesic DA, Eisner JR, Kemnitz JW, Goy RW: The prenatally androgenized female rhesus monkey as a model for PCOS. In Androgen excess disorders in women Edited by: Azziz R, Nestler JE, Dewailly D. Philadelphia, Lippincott-Raven; 1997:369-382.

58. Steiner RA, Clifton DK, Spies HG, Resko JA: Sexual differentiation and feedback control of luteinizing hormone secretion in the rhesus monkey. Biol Reprod 1976, I 5:206-2 I 2 .

59. Robinson JE, Forsdike RA, Taylor JA: In utero exposure of female lambs to testosterone reduces the sensitivity of the gonadotropin-releasing hormone neuronal network to inhibition by progesterone. Endocrinology 1999, I40:5797-5805.

60. Sarma HN, Manikkam M, Herkimer C, Dell'Orco J, Welch KB, Foster DL, Padmanabhan V: Fetal programming: excess prenatal testosterone reduces postnatal LH, but not FSH responsiveness to estradiol negative feedback in the female. Endocrinology 2005, |46:428|-429|.

61. Abbott DH, Dumesic DA, Franks S: Developmental origin of polycystic ovary syndrome - a hypothesis. J Endocrinol 2002, I 74: I-5

62. Abbott DH, Zhou R, Bruns CM, Bird IM, Kemnitz JW, Turk JM, Dumesic DA: Pioglitazone normalizes menstrual cycle duration and improves insulin sensitivity in a nonhuman primate model for polycystic ovary syndrome (PCOS). Volume 90. Abstract OR 14-3 presented at the 86th Annual Meeting of the Endocrine Society, New Orleans, LA; 2004.

63. Eisner JR, Dumesic DA, Kemnitz JW, Abbott DH: Timing of prenatal androgen excess determines differential impairment in insulin secretion and action in adult female rhesus monkeys. I Clin Endocrinol Metab 2000, 85: | 206-1210.

64. Recabarren SE, Padmanabhan V, Codner E, Lobos A, Duran C, Vidal M, Foster DL, Sir-Petermann T: Postnatal developmental consequences of altered insulin sensitivity in female sheep treated prenatally with testosterone. Am J Physiol Endocrinol Metab 2005, 289:E80 I-E806

65. Eisner JR, Dumesic DA, Kemnitz JW, Colman RJ, Abbott DH: Increased adiposity in female rhesus monkeys exposed to androgen excess during early gestation. Obes Res 2003 , I I:279-286.

66. Steckler T, Wang J, Bartol FF, Roy SK, Padmanabhan V: Fetal programming: prenatal testosterone treatment causes intrauterine growth retardation, reduces ovarian reserve and increases ovarian follicular recruitmen. Endocrinology 2005, 146:3185-3193.

67. Maciel GA, Baracat EC, Benda JA, Markham SM, Hensinger K, Chang RJ, Erickson GF: Stockpiling of transitional and classic primary follicles in ovaries of women with polycystic ovary syndrome. J Clin Endocrinol Metab 2004, 89:532 I-5327.

68. Johnson J, Canning J, Kaneko T, Pru JK, Tilly JL: Germline stem cells and follicular renewal in the postnatal mammalian ovary. Nature 2004, 428: I45-I50.

69. Dumesic DA, Schramm RD, Bird IM, Peterson E, Paprocki AM, Zhou $\mathrm{R}$, Abbott $\mathrm{DH}$ : Reduced intrafollicular androstenedione and 
estradiol levels in early-treated prenatally androgenized female rhesus monkeys receiving follicle-stimulating hormone therapy for in vitro fertilization. Biol Reprod 2003, 69:1213-1219.

70. Dumesic DA, Schramm RD, Abbott DH: Early origins of polycystic ovary syndrome. Reprod Fertil Dev 2005, 17:349-360.

71. Hickey TE, Marrocco DL, Amato F, Ritter LJ, Norman RJ, Gilchrist $\mathrm{RB}$, Armstrong DT: Androgens augment the mitogenic effects of oocyte-secreted factors and growth differentiation factor 9 on porcine granulosa cells. Biol Reprod 2005, 73:825-832.

72. Zheng P, Si W, Bavister BD, Yang J, Ding C, Ji W: I 7Beta-estradiol and progesterone improve in-vitro cytoplasmic maturation of oocytes from unstimulated prepubertal and adult rhesus monkeys. Hum Reprod 2003, 18:2137-2144.

73. Tesarik J, Mendoza C: Nongenomic effects of $\mathbf{1 7}$ beta-estradiol on maturing human oocytes: relationship to oocyte developmental potential. J Clin Endocrinol Metab 1995, 80: I438-1443.

74. Rom E, Reich R, Laufer N, Lewin A, Rabinowitz R, Pevsner B, Lancet M, Shenker JG, Miskin R, Adelmann-Grill BC, Tsafriri A: Follicular fluid contents as predictors of success of in-vitro fertilizationembryo transfer. Hum Reprod 1987, 2:505-5I0.

75. Kreiner D, Liu HC, Itskovitz J, Veeck L, Rosenwaks Z: Follicular fluid estradiol and progesterone are markers of preovulatory oocyte quality. Fertil Steril 1987, 48:991-994.

76. Wallen $\mathrm{K}$, Baum MJ: Masculinization and defeminization in altricial and precocial mammals: comparative aspects of steroid hormone action. In Hormones, Brain and Behavior Volume 4. Edited by: Pfaff DW, Arnold AP, Etgen AM, Fahrbach SE, Rubin RT. San Diego, Academic Press; 2002:385-423.

77. Haney AF, Newbold RR, McLachlan JA: Prenatal diethylstilbestrol exposure in the mouse: effects on ovarian histology and steroidogenesis in vitro. Biol Reprod 1984, 30:47|-478.

78. McLachlan JA, Newbold RR, Bullock BC: Long-term effects on the female mouse genital tract associated with prenatal exposure to diethylstilbestrol. Cancer Res 1980, 40:3988-3999.

79. Wu CH, Mangan CE, Burtnett MM, Mikhail G: Plasma hormones in DES-exposed females. Obstet Gynecol 1980, 55:157-162.

80. Pomerance W: Post-stilbestrol secondary syndrome. Obstet Gynecol 1973, 42:12.

8I. Bibbo M, Gill WB, Azizi F, Blough R, Fang VS, Rosenfield RL, Schumacher GF, Sleeper K, Sonek MG, Wied GL: Follow-up study of male and female offspring of DES-exposed mothers. Obstet Gynecol 1977, 49:1-8.

82. Barnes $A B$ : Menstrual history of young women exposed in utero to diethylstilbestrol. Fertil Steril |979, 32: |48-I53.

83. Couse JF, Dixon D, Yates M, Moore AB, Ma L, Maas R, Korach KS: Estrogen receptor-alpha knockout mice exhibit resistance to the developmental effects of neonatal diethylstilbestrol exposure on the female reproductive tract. Dev Biol 200I, 238:224-238.

84. Sharpe RM, Franks S: Environment, lifestyle and infertility - an inter-generational issue. Nat Cell Biol 2002:s33-s40.

85. Hughes CL, Mathur R, Geller D: Environmental factors in polycystic ovary syndrome: Are there plausible cause-and-effect hypotheses? In Polycystic Ovary Syndrome Edited by: Chang RJ, Heindel J], Dunaif A. Marcel Dekker, Inc., New York, NY; 2002:287-306.

86. Gupta C: Reproductive malformation of the male offspring following maternal exposure to estrogenic chemicals. Proc Soc Exp Biol Med 2000, 224:6 I-68.

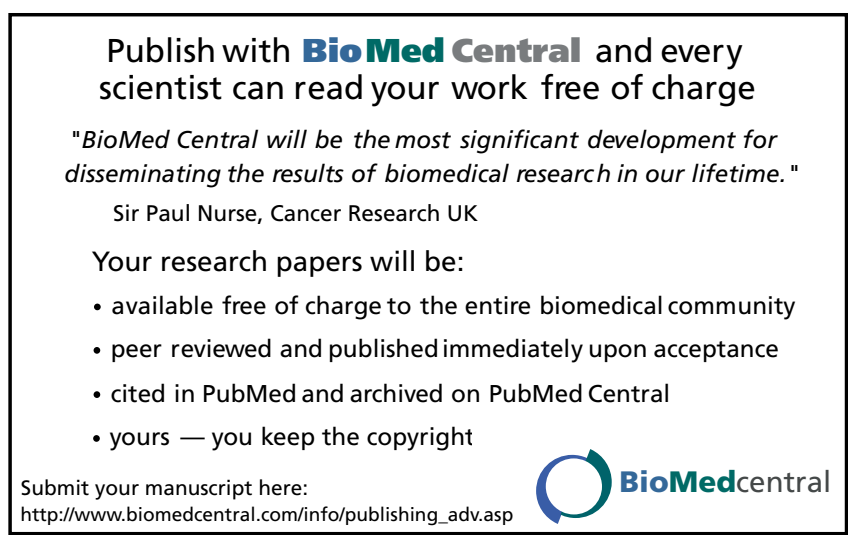

